\title{
Determination of mineral concentrations in stem and seed of Juncus acutus
}

\author{
Funda ERDEM ${ }^{1, a, ®}$, Nurcan ÇETINKAYA $^{2, b}$ \\ ${ }^{1}$ Ministry of Health, Public Health Laboratory, Department of Moleculer Microbiology, Samsun, Turkey; ${ }^{2}$ Ondokuz Mayis \\ University, Faculty of Veterinary Medicine, Department of Animal Nutrition and Nutritional Diseases, Samsun,Turkey. \\ aORCID:0000-0002-6006-7405; ' ORCID:0000-0002-9977-2937 \\ ${ }^{凶}$ Corresponding author: fundaerdemtr@gmail.com \\ Received date: 28.05 .2019 - Accepted date: 31.12 .2019
}

\begin{abstract}
The objective of this study was to determine micro and macro mineral concentrations in stem and seed of Juncus acutus for ruminant nutrition. The samples of Juncus acutus stem and seed were randomly collected from Kizilirmak Delta, Samsun, Turkey. Micro and macro mineral concentrations of samples were analyzed by using an inductively coupled plasma mass spectrophotometer (ICP-MS) and ion chromatography (IC) methods, respectively. Differences between mean concentrations of B, Al, $\mathrm{Cr}, \mathrm{Mn}, \mathrm{Fe}, \mathrm{Co}, \mathrm{Ni}, \mathrm{Cu}, \mathrm{Zn}$ and $\mathrm{Se}$ in stem and seed of Juncus acutus samples were significant $(\mathrm{P}<0.05)$. The mean values of $\mathrm{Al}$, Cr, $\mathrm{Fe}, \mathrm{Co}, \mathrm{Ni}$ and $\mathrm{Se}$ for stem of Juncus acutus were higher than values for seed of Juncus acutus but, the mean values of $\mathrm{Mn}, \mathrm{Cu}$ and $\mathrm{Zn}$ for seed of Juncus acutus were higher than stem of Juncus acutus $(\mathrm{P}<0.05)$. The concentrations of Na, $\mathrm{K}$ and Ca in stem were higher than seed of Juncus acutus. On the other hand, the concentration of $\mathrm{Mg}$ for seed of Juncus acutus were higher than stem of Juncus acutus $(\mathrm{P}<0.05)$. In conclusion, the obtained results show that stem and seed of Juncus acutus may be a good source to meet the micro and macro mineral requirements of ruminant animals. Besides, the seeds of Juncus acutus may also provide micro and macro minerals to birds in wetlands.
\end{abstract}

Keywords: Juncus acutus, macro mineral, micro mineral, wetland

\section{Juncus acutus'un gövde ve tohumunda mineral konsantrasyonlarının belirlenmesi}

Özet: Bu çalışmanın amacı Juncus acutus'un gövde ve tohumunda bulunan makro ve mikro mineral konsantrasyonlarının ruminanat besleme için belirlenmesidir. Türkiye, Samsun ili Kızılırmak Deltası'ndan Juncus acutus'un gövde ve tohum örnekleri rastgele toplandı. Örneklerin mikro mineral analizleri indüktif olarak eşleştirilmiş plazma kütle spektrofotometresi (ICP-MS) ile, makro mineral analizleri iyon kromotografisi (IC) ile yapıldı. Juncus acutus'un gövde ve tohumu B, Al, Cr, Mn, Fe, Co, Ni, Cu, Zn ve Se mineralleri yönünden karşılaştırıldığında aralarında önemli farklılıklar tespit edilmiştir $(\mathrm{P}<0,05)$. Al, $\mathrm{Cr}, \mathrm{Fe}, \mathrm{Co}$, Ni ve Se minerallerinin ortalama değerleri Juncus acutus'un gövdesinde tohumuna oranla daha yüksek fakat $\mathrm{Mn}, \mathrm{Cu}$ ve $\mathrm{Zn}$ mineralleri ise tohumda gövdeye göre daha yüksek bulunmuştur ( $\mathrm{P}<0,05)$. Juncus acutus'un gövdesindeki $\mathrm{Na}$, K ve Ca konsantrasyonları Juncus acutus'un tohumundan daha yüksek bulunmuştur $(\mathrm{P}<0,05)$. Diğer taraftan Juncus acutus'un tohumunda Mg konsantrasyonu Juncus acutus'un gövdesinden daha yüksek bulunmuştur $(\mathrm{P}<0,05)$. Sonuç olarak, bulunan sonuçlar ruminant hayvanların mikro ve makro mineral ihtiyaçlarının karşılanmasında Juncus acutus'un gövde ve tohumunun iyi bir kaynak olabileceğini göstermektedir. Bununla birlikte Juncus acutus'un tohumları sulak alanlarda yaşayan kuşlar için de mikro ve makro mineral kaynağı olabilirler.

Anahtar sözcükler: Juncus acutus, makro mineral, mikro mineral, sulak alan

\section{Introduction}

Wetlands represent some of the most productive habitat on earth. They are often referred to as "nature's kidneys" because of their ability to filter, metabolize, and sequester nutrients and minerals. Plant species play an important function in wetland geochemistry because they are the main living collectors and transporters of micro minerals through active and passive absorption (29). Salt marsh plants generally accumulate different levels of minerals in the below and aboveground parts. The availability of minerals for plants may be affected by several factors: their loading rates, chemical characteristics, $\mathrm{pH}$, soil texture, clay, and organic matter contents, etc. (26). Several other factors also affect the uptake of micro minerals and heavy metals, including differences in plant age and growth stages, seasonal 
variations, tidal inundations, and salinity $(6,27)$. Some of micro minerals are essential and these elements $(\mathrm{Cu}, \mathrm{Zn}$, $\mathrm{Fe}, \mathrm{Mn}$ and $\mathrm{Mo}$ ) play biochemical and physiological functions in plants and animals. On the other hand, heavy metals are highly toxic elements such as $\mathrm{Hg}, \mathrm{Pb}, \mathrm{As}$ and $\mathrm{Ba}$. Metals in halophytes are mainly accumulated in the roots, with small quantities translocated to the stems and leaves (30). According to Hosseini Alhashemi et al. (15) reported that uptake trend of micro minerals in plant decreases as root>stem>leaf. The extent and pattern of mineral deficiencies/excess in plants vary in different agro-climatic conditions as available mineral content in green vegetation depends on physical and chemical properties of soil, soil erosion, cropping pattern, fertilizer/chemical application, species and genetic variation in plants, stage of maturation, presence of other minerals etc. (19).

Juncus acutus (Juncaceae) is a long-lived and common plant of wetlands. There are around 300 species of Juncus acutus and they present worldwide. There are about 2549.2 ha of natural grassland in the Kizilirmak Delta. Juncus acutus presents mainly in Yorukler, Doganca and Sarikoy districts of Bafra, Samsun, Turkey, the production capacity of Juncus acutus is 8.650 tons (10). Juncus acutus are consumed by water buffaloes and cattle in Kizilirmak Delta. Phenolic compounds and antioxidant activity of stem and seed of Juncus acutus plant were determined by Erdem et al. (12). Effects of different Juncus acutus maize silage ratios on digestibility and rumen cellulolytic bacteria were reported by Cetinkaya and Erdem (7). Organic matter digestibility and metabolisable energy values of Juncus acutus and the effects of Juncus acutus on cellulolitic bacteria in rumen were studied (11).

However, no information is avaiable regarding to the concentrations of micro and macro minerals in stem and seed of Juncus acutus for animal nutrition. The objective of this study was to detemine macro minerals $\mathrm{Na}, \mathrm{K}, \mathrm{Ca}$, $\mathrm{Mg}$ and $\mathrm{NH}_{4}$; micro minerals $\mathrm{B}, \mathrm{Al}, \mathrm{Cr}, \mathrm{Mn}, \mathrm{Fe}, \mathrm{Co}, \mathrm{Ni}$, $\mathrm{Cu}, \mathrm{Zn}$ and $\mathrm{Se}$ values in the stem and seed of Juncus acutus for mineral nutrition of animals.

\section{Material and Methods}

Feed material: Seed of Juncus acutus samples was collected randomly by hand, and stem samples were collected from 20 plants in August 2017 from Kizilirmak Delta, Samsun, Turkey. The GPS coordinates of sampling locations were shown below.

- 36 19' 53 81" E, 41 16' 30 29" N

• 36 6' 5152 " E, 4136 ' 24 24" N

- $365^{\prime} 33$ 18" E, $4138^{\prime} 1685^{\prime \prime} \mathrm{N}$

The month August was chosen for sample collection because of seeds availability. The stems were chopped into small pieces with garden scissors. Samples were weighed and dried in an oven at $65^{\circ} \mathrm{C}$ for $48 \mathrm{~h}$. After drying, all stems and seeds were ground in a mill to pass through a $1 \mathrm{~mm}$ screen, and kept in plastic boxes until mineral analysis. Duplicate samples were prepared for each analysis.

Mineral analysis: The micro mineral concentrations $\mathrm{B}, \mathrm{Al}, \mathrm{Cr}, \mathrm{Mn}, \mathrm{Fe}, \mathrm{Co}, \mathrm{Ni}, \mathrm{Cu}, \mathrm{Zn}$ and $\mathrm{Se}$ were determined by ICP-MS(ICP-MS, Agilent-7700 Model) and macro mineral concentrations $\left(\mathrm{Na}, \mathrm{K}, \mathrm{Ca}, \mathrm{Mg}\right.$ and $\left.\mathrm{NH}_{4}\right)$ were determined through an IC (IC, Dionex ICS 3000 Model) at the Department of Moleculer Microbiology, Public Health Laboratory, Ministry of Health, 55060 Samsun, Turkey.

$0.5 \mathrm{~g}$ in $1 \mathrm{~mm}$ dimension stem and seed of Juncus acutus samples were put into vessels and a mixture composed of $10 \mathrm{ml}$ of concentrated $\mathrm{HNO}_{3}, 3 \mathrm{~mL}$ of concentrated $\mathrm{HCl}$ and $2 \mathrm{~mL} \mathrm{H}_{2} \mathrm{O}_{2}$ was added to each vessel. They were placed in Microwave Oven (Model CEM Mars) and were digested at two steps, first 15 min at $180{ }^{\circ} \mathrm{C}$ then after secondly $30 \mathrm{~min}$ at $200{ }^{\circ} \mathrm{C}(22)$. The resulting liquid samples were diluted with deionized water to bring the volume up to $50 \mathrm{ml}$ for micro minerals analysis by ICP-MS and macro mineral analysis by IC.

The concentrations of $\mathrm{B}, \mathrm{Al}, \mathrm{Cr}, \mathrm{Mn}, \mathrm{Fe}, \mathrm{Co}, \mathrm{Ni}, \mathrm{Cu}$, $\mathrm{Zn}$ and $\mathrm{Se}$ in Juncus acutus stem and seed samples were measured by ICP-MS method (2). The levels of $\mathrm{Na}^{+}, \mathrm{K}^{+}$, $\mathrm{Ca}^{+2}, \mathrm{Mg}^{+2}$ and $\mathrm{NH}_{4}{ }^{+}$in all samples were measured by IC method (18).

Statistical analysis: The micro minerals concentrations (B, Al, Cr, Mn, Fe, Co, Ni, Cu, $\mathrm{Zn}$ and $\mathrm{Se}$ ) and macro mineral concentrations ( $\mathrm{Na}, \mathrm{K}, \mathrm{Ca}, \mathrm{Mg}$ and $\mathrm{NH}_{4}$ ) were performed by one-way analysis of variance (ANOVA) test (24). Means differences were considered significant at $\mathrm{P}<0.05$.

\section{Results}

The estimated micro minerals $\mathrm{B}, \mathrm{Al}, \mathrm{Cr}, \mathrm{Mn}, \mathrm{Fe}, \mathrm{Co}$, $\mathrm{Ni}, \mathrm{Cu}, \mathrm{Zn}$ and $\mathrm{Se}$ concentrations in stem and seed of Juncus acutus are shown in Table 1. Diferences between mean values of stem and seed samples were significant $(\mathrm{P}<0.05)$. The mean values of $\mathrm{Al}, \mathrm{Cr}, \mathrm{Fe}, \mathrm{Co}, \mathrm{Ni}$ and $\mathrm{Se}$ for stem of Juncus acutus were higher than the estimated values for seed of Juncus acutus, but the mean values of $\mathrm{Mn}, \mathrm{Cu}$ and $\mathrm{Zn}$ for seed of Juncus acutus were higher than the estimated values for stem of Juncus acutus.

The estimated macro mineral $\mathrm{Na}, \mathrm{K}, \mathrm{Ca}, \mathrm{Mg}$ and $\mathrm{NH}_{4}$ concentrations of stem and seed of Juncus acutus are shown in Table 2. The concentrations of $\mathrm{Na}, \mathrm{K}$ and $\mathrm{Ca}$ for stem of Juncus acutus were higher as compared to those in the seed of Juncus acutus. On the other hand, the levels of $\mathrm{Mg}$ and $\mathrm{NH}_{4}$ for seed of Juncus acutus were higher than the repoted levels for stem of Juncus acutus. 
Table 1. Micro mineral concentrations of stem and seed of Juncus acutus (mean $\pm \mathrm{SE}, \mathrm{n}=20$ )

\begin{tabular}{ccc}
\hline & Juncus acutus & \\
\hline $\begin{array}{c}\text { Micro mineral } \\
(\mathbf{m g} / \mathbf{k g})\end{array}$ & $\begin{array}{c}\text { Stem } \\
\left(\mathbf{x}^{-} \pm \mathbf{S} \mathbf{x}^{-}\right)\end{array}$ & $\begin{array}{c}\text { Seed } \\
\left(\mathbf{x}^{-} \pm \mathbf{S x}^{-}\right)\end{array}$ \\
\hline $\mathrm{B}$ & $17.77 \pm 1.25$ & $28.25 \pm 1.74$ \\
$\mathrm{Al}$ & $129.9 \pm 7.6$ & $43.25 \pm 2.01$ \\
$\mathrm{Cr}$ & $7.82 \pm 1.11$ & $0.300 \pm 0.010$ \\
$\mathrm{Mn}$ & $17.23 \pm 1.21$ & $43.75 \pm 2.23$ \\
$\mathrm{Fe}$ & $153.0 \pm 5.4$ & $50.51 \pm 1.96$ \\
$\mathrm{Co}$ & $0.12 \pm 0.02$ & $0.030 \pm 0.001$ \\
$\mathrm{Ni}$ & $13.84 \pm 1.14$ & $\mathrm{ND}$ \\
$\mathrm{Cu}$ & $3.70 \pm 0.98$ & $5.95 \pm 0.94$ \\
$\mathrm{Zn}$ & $4.32 \pm 0.87$ & $11.24 \pm 1.03$ \\
$\mathrm{Se}$ & $0.11 \pm 0.02$ & $0.070 \pm 0.010$ \\
\hline
\end{tabular}

ND: Not dedectable. SE: Standart error of the mean. Differences between mean values of stem and seed samples in the same row were significant $(\mathrm{P}<0.05)$.

Table 2. Macro mineral concentrations of stem and seed of Juncus acutus (mean $\pm \mathrm{SE}, \mathrm{n}=20$ )

\begin{tabular}{ccc}
\hline & Juncus acutus & \\
\hline Macro mineral $(\mathbf{g} / \mathbf{k g})$ & $\begin{array}{c}\text { Stem } \\
\left(\mathbf{x}^{-} \pm \mathbf{S} \mathbf{x}^{-}\right)\end{array}$ & $\begin{array}{c}\text { Seed } \\
\left(\mathbf{x}^{-} \pm \mathbf{S x}^{-}\right)\end{array}$ \\
\hline $\mathrm{Na}$ & $0.900 \pm 0.020$ & $0.140 \pm 0.010$ \\
$\mathrm{NH}_{4}$ & $0.020 \pm 0.006$ & $0.037 \pm 0.005$ \\
$\mathrm{~K}$ & $11.04 \pm 1.00$ & $8.50 \pm 0.09$ \\
$\mathrm{Mg}$ & $0.160 \pm 0.030$ & $0.310 \pm 0.020$ \\
$\mathrm{Ca}$ & $0.380 \pm 0.020$ & $0.260 \pm 0.020$ \\
\hline
\end{tabular}

SE: Standart error of the mean. Differences between mean values of stem and seed samples in the same row were significant $(\mathrm{P}<0.05)$.

\section{Discussion and Conclusion}

The Fe (153.0 mg/kg), Cr (7.82 mg/kg) and Ni (13.84 $\mathrm{mg} / \mathrm{kg}$ ) levels for stem of Juncus acutus were higher than those of levels for stem of Juncus acutus grown in Rio Naracauli $(112.0 \mathrm{mg} / \mathrm{kg}, 4.80 \mathrm{mg} / \mathrm{kg}, 2.90 \mathrm{mg} / \mathrm{kg})$, respectively. The $\mathrm{Zn}(4.32 \mathrm{mg} / \mathrm{kg})$ levels for stem of Juncus acutus was lower than that of Juncus acutus grown in Rio Naracauli $(290 \mathrm{mg} / \mathrm{kg})$ but Co $(0.120 \mathrm{mg} / \mathrm{kg} ; 0.120$ $\mathrm{mg} / \mathrm{kg}$ ) and $\mathrm{Cu}(3.70 \mathrm{mg} / \mathrm{kg} ; 3.90 \mathrm{mg} / \mathrm{kg})$ levels were similar to each other (20). The $\mathrm{Fe}(153.0 \mathrm{mg} / \mathrm{kg})$ and $\mathrm{Cu}$ $(3.70 \mathrm{mg} / \mathrm{kg}$ ) levels for stem of Juncus acutus were similar to those of Festuca ovina $(148.0 \mathrm{mg} / \mathrm{kg}$ and Bromus variegatus $(4.06 \mathrm{mg} / \mathrm{kg})$, respectively. $\mathrm{Mn}(17.23 \mathrm{mg} / \mathrm{kg})$ levels for stem of Juncus acutus was similar to that of Trifolium montanum $(18.18 \mathrm{mg} / \mathrm{kg})$. B $(17.77 \mathrm{mg} / \mathrm{kg})$ levels for stem of Juncus acutus was similar to that of Vicia cracca $(17.02 \mathrm{mg} / \mathrm{kg})$. On the other hand, The $\mathrm{Cu}$ $(5.95 \mathrm{mg} / \mathrm{kg}), \mathrm{Mn}(43.75 \mathrm{mg} / \mathrm{kg})$ and B $(28.25 \mathrm{mg} / \mathrm{kg})$ levels for seed of Juncus acutus were similar to those of Lotus corniculatus and Trifolium montanum (5.530 $\mathrm{mg} / \mathrm{kg} ; 5.640 \mathrm{mg} / \mathrm{kg})$, Bromus variegatus $(43.53 \mathrm{mg} / \mathrm{kg}$ ) and Medicago sativa (27.09 mg/kg), respectively (14).
The Mn $(43.75 \mathrm{mg} / \mathrm{kg})$ and $\mathrm{Zn}(11.24 \mathrm{mg} / \mathrm{kg})$ levels for seed of Juncus acutus were similar to those of Vicia sativa $(49.00 \mathrm{mg} / \mathrm{kg}, 13.00 \mathrm{mg} / \mathrm{kg}$ ), respectively and It was also found similar to $\mathrm{Zn}(11.00 \mathrm{mg} / \mathrm{kg})$ levels of Lupinus albus (8). The $\mathrm{Al}(129.0 \mathrm{mg} / \mathrm{kg})$, Ni (13.84 mg/kg) and $\mathrm{Zn}$ $(4.32 \mathrm{mg} / \mathrm{kg})$ levels for stem of Juncus acutus were lower than those of Typha domingensis $(358.0 \mathrm{mg} / \mathrm{kg} ; 48.40$ $\mathrm{mg} / \mathrm{kg} ; 126.0 \mathrm{mg} / \mathrm{kg}$ ), but higher than those of Arundo donax $(15.50 \mathrm{mg} / \mathrm{kg} ; 0.97 \mathrm{mg} / \mathrm{kg} ; 1.93 \mathrm{mg} / \mathrm{kg})$, respectively (4). The Cu levels of Juncus acutus (3.70 $\mathrm{mg} / \mathrm{kg}$ ) and Myriophyllum verticillatum $(3.23 \mathrm{mg} / \mathrm{kg}$ ) were similar to each other. Beside the $\mathrm{Fe}$ (11528.0 $\mathrm{mg} / \mathrm{kg} ; 153.0 \mathrm{mg} / \mathrm{kg}), \mathrm{Zn}(35.46 \mathrm{mg} / \mathrm{kg} ; 4.32 \mathrm{mg} / \mathrm{kg})$ and Mn $(9113.0 \mathrm{mg} / \mathrm{kg} ; 17.23 \mathrm{mg} / \mathrm{kg})$ levels of Myriophyllum verticillatum were higher than those of Juncus acutus, respectively (9). Singh et al. (25) reported that the levels of $\mathrm{Cr}, \mathrm{Cu}$ and $\mathrm{Fe}$ for stem of Panicum antidolate were found ND; ND and $0.87 \mathrm{mg} / \mathrm{kg}$, respectively. Morever, these results lower than those for stem of Juncus acutus. The Co levels for stem of Juncus acutus $(7.82 \mathrm{mg} / \mathrm{kg})$ was higher than that of Myriophyllum spicatum $(5.34 \mathrm{mg} / \mathrm{kg}$ ) (31). The B $(11.00 \mathrm{mg} / \mathrm{kg} ; 17.77 \mathrm{mg} / \mathrm{kg})$ and $\mathrm{Se}(<0.05$ 
$\mathrm{mg} / \mathrm{kg} ; 0.110 \mathrm{mg} / \mathrm{kg}$ ) levels for stem of Phragmites australis were lower than those of Juncus acutus, respectively. However, the Co levels was similar to each other $(0.120 \mathrm{mg} / \mathrm{kg})(3)$. The $\mathrm{Cu}(6.41 \mathrm{mg} / \mathrm{kg} ; 4.67 \mathrm{mg} / \mathrm{kg}$; $3.70 \mathrm{mg} / \mathrm{kg})$ and $\mathrm{Zn}(9.480 \mathrm{mg} / \mathrm{kg} ; 13.57 \mathrm{mg} / \mathrm{kg} ; 4.320$ $\mathrm{mg} / \mathrm{kg}$ ) levels of Alisma gramineum and Sparganium emersus were higher than those of Juncus acutus, respectively (16). The $\mathrm{Mn}(17.23 \mathrm{mg} / \mathrm{kg})$ and $\mathrm{Cu}(3.700$ $\mathrm{mg} / \mathrm{kg}$ ) levels of Juncus acutus were lower than those of Juncus maritumus $(48.60 \mathrm{mg} / \mathrm{kg}$ and $8.02 \mathrm{mg} / \mathrm{kg})$, Juncus effusus $(140.0 \mathrm{mg} / \mathrm{kg}$ and $7.430 \mathrm{mg} / \mathrm{kg}$ ) and Juncus articulatus $(218.0 \mathrm{mg} / \mathrm{kg}$ and $14.80 \mathrm{mg} / \mathrm{kg}$ ), respectively (28). In the other research, $\mathrm{Cr}(0.42 \mathrm{mg} / \mathrm{kg} ; 7.82)$ and $\mathrm{Ni}$ $(0.43 \mathrm{mg} / \mathrm{kg} ; 13.84 \mathrm{mg} / \mathrm{kg})$ levels of stem of Juncus maritimus were lower than those of stem of Juncus acutus in our study, respectively (1). The $\mathrm{Al}(17.23 \mathrm{mg} / \mathrm{kg} ; 558.1$ $\mathrm{mg} / \mathrm{kg})$, Co $(0.12 \mathrm{mg} / \mathrm{kg} ; 0.60 \mathrm{mg} / \mathrm{kg})$ and $\mathrm{Fe}(153.0$ $\mathrm{mg} / \mathrm{kg} ; 500.5 \mathrm{mg} / \mathrm{kg}$ ) levels of Juncus acutus were lower than those of Sueda maritim (21). Regarding the element mobility from roots to stems, translocation factors were more variable among plants rather than among elements, and showed their highest mean values in the congener species Juncus maritimus and Juncus acutus, which, however have different life forms (5).

The obtained $\mathrm{Na}$ and $\mathrm{K}$ levels were in line with the published range for wheat staw and triticale straw (13). Mineral concentrations in forage vary widely among species, and are influenced by many soil and other factors including growth stage, plant part, climate and fertilizer application $(23,17)$.

In conclusion, the estimated macro and micro mineral concentrations of both stem and seed samples of Juncus acutus showed that micro and macro minerals might be a good source for meeting mineral requirements of ruminant animals. Even, seeds of plant may provide necessary levels of macro and micro minerals to birds during summer and fall seasons in Kızılırmak delta.

\section{Acknowledgements}

The authors would like to thank to Ondokuz Mayis University and Public Health Laboratory, Ministry of Health for providing research facilities.

\section{Financial Support}

This research received no grant from any funding agency/sector.

\section{Ethical Statement}

This study does not present any ethical concerns.

\section{Conflict of interest}

The authors declare that they have no conflict of interest.

\section{References}

1. Almeida CMR, Mucha A, Vasonce Los MCSD (2004): Influence of the sea rush juncus maritimus on metal concentration and speciation in estuarine sediment colonized by the plant. Environ Sci Technol, 38, 3112-3118.

2. Anike FN, Yusuf M, Isikhuemhen OS (2016): Co-Substrating of peanut shells with cornstalks enhances biodegradation by pleurotus ostreatus. J Bioremed Biodeg, 7, 327-334.

3. Bonanno G (2011): Micro minerals accumulation and distribution in the organs of Phragmitesaustralis (common reed) and biomonitoring applications. Ecotoxicol Environ Saf, 74, 1057-1064.

4. Bonanno G (2013): Comparative performance of micro minerals bioaccumulation and biomonitoringin the plant species Typha domingensis, Phragmites australis and Arundo donax. Ecotoxicol Environ Saf, 97, 124-130.

5. Bonanno G, Vymazal J, Cirelli GR (2018): Translocation, accumulation and bioindication of trace elements in wetland plants. Sci of the Total Environ, 631632, 252-261.

6. Cacador I, Vale C, Catarino F (2000): Seasonal variation of $\mathrm{Zn}, \mathrm{Pb}, \mathrm{Cu}$ and $\mathrm{Cd}$ concentrations in the root sediment system of Spartina maritime and Halimione portulacoides from Tagus estuary salt marshes. Mar Environ Res, 49, 279290.

7. Cetinkaya N, Erdem F (2015): Effects of different Juncus acutus: maise silage ratios on digestibility and rumen cellulolytic bacteria. Kafkas Univ Vet Fak Derg, 21, 499505.

8. Ceylan S, Yoldas F, EImacı O, et al (2016): Effect of green manure on yield and mineral nutrient content of pumpkin grown in sandy loam soil. Ege Üniv Ziraat Fak Derg, 53, 75-381.

9. Engin MS, Uyanık A, Cay S (2017): Investigation of micro metals distribution in water, sediments and wetland plants of Kizilırmak Delta, Turkey. Int J Sed Res, 32, 90-97.

10. Erdem F (2014): Determination the digestibility of Juncus acutusby in-vitro gas production and its effect on ruminal cellulolytic bacteria by real-time PCR methods. $\mathrm{PhD}$ Thesis, Ondokuz Mayıs University, Graduate School of Health Sciences, Samsun.

11. Erdem F, Cetinkaya N (2016): Digestibility of Juncus acutus and its effects on ruminal cellulolytic bacteria. Italian J Agric Sci, 15, 69-75.

12. Erdem F, Cetinkaya N, Nisbet C, et al (2015): Estimation organic matter digestibility, metabolisable energy, phenolic compounds and antioxidant activity of stem and seed of Juncus acutus plant for ruminants. South African J Anim Sci, 45, 502-509.

13. Feedipedia (2017) Animal Feed Resources Information System INRA CIRAD AFZ and FAO. Available at http://www.feedipedia.org/node/12167. (Accessed February 12, 2019).

14. Gursoy E, Muhlis M (2017): Determination of mineral contents of some legume and cereal forages grown as naturally in pastures of Erzurum province. Alinteri J Agric Sci, 32 (1), 1-9.

15. Hosseini Alhashemi AS, Karbassi AR, Hassanzadeh Kiabi B, et al (2011): Bioaccumulation of micro minerals 
in trophic levels of wetland plants and waterfowl birds. Biol Micro Elem Res, 142, 500-516.

16. Jamnıcká G, Hrivnák R, Ot’ahel'ová $\mathbf{H}$, et al (2006): Heavy metals content in aquatic plant species from some aquatic biotopes in Slovakia. 336-370. In: Proocedings of $36^{\text {th }}$ Internat Conf of IAD. Austrian Committee Danube Research/IAD

17. Judson GJ, Mcfarlane JD (1998): Mineral disorders in grazing livestock and the usefulness of soil and plant analysis in the assessment of these disorders. Aust J Experi Agric, 38, 707-723.

18. Kuniyal JC, Sharma M, Chand K, et al (2015): Water soluble ionic components in particulate matter (PM10) during high pollution episode days at Mohal and Kothi in the North-Western Himalaya, India. Aerosol Air Qual Res, 15, 529-543.

19. Mcdowell LR, Conrad JH, Ellis GL, et al (1983): Minerals for grazing ruminants in tropical regions. Extension bulletin 1149, Animal Science Department, University of Florida, Gainesville.

20. Medas D, De Giudici G, Pusceddu C, et al (2019): Impact of $\mathrm{Zn}$ excess on biomineralization processes in Juncus acutus grown in mine polluted sites. J Hazard Mater, 370, 98-107.

21. Milic D, Lukovic J, Ninkov J, et al (2012): Heavy metal content in halophytic plants from inland and maritime saline areas. Cent Eur J Biol, 7, 307-317.

22. Miller RO (1998): Microwave digestion of plant tissue in a closed vessel. 69-73. In, Kalra YP(Ed): Handbook of reference methods for plant analysis. CRC Press, New York.
23. Minson DJ (1990): Forage in ruminants. Academic Press Inc. San Diego, California, USA.

24. SAS (2007): SAS Statistic Software, SAS Campus Drive. Cary NC, USA.

25. Singh N, Kaur M, Kaur Katnoria J (2017): Analaysis on biaccumulaton of metals in aquatic environment od Beas River Basin: Acase study from Kanjli wetland. Geo Health, 1, 93-105.

26. Sousa AI, Cacador I, Lillebo AI, et al (2008): Heavy metal accumulation in Halimione portulacoides: Intra- and extracellular metal binding sites. Chemosphere, 70, 850-857.

27. Sundby B, Vale C, Caçador I, et al (1998): Metal-rich concretions on the roots of salt marsh plants: Mechanism and rate of formation. Limnol Oceanogr, 43, 245-252.

28. Teuchies J, Jacobs S, Oosterlee L, et al (2013): Role of plants in metal cycling in a tidal wetland: Implications for phytoremidiation. Sci Total Environ, 445-446, 146-154.

29. Vodyanitskii YN, Shoba SA (2015): Biogeochemistry of carbon, iron, and heavy metals in wetlands (analytical review). Moscow Univ Soil Sci Bull, 70, 89-97.

30. Windham L, Weis JS, Weise P (2003): Uptake and distribution of metals in two dominant salt marsh macrophytes, Spartina alternifolia (cordgrass) and Phragmites australis (common reed). Mar Environ Res, 56, 63-72.

31. Yabanlı M, Yozukmaz A, Sel F (2014): Heavy Metal accumulation in the leaves, stem and root of the invasive submerged macrophyte Myriophyllum spicatum $L$. (Haloragaceae): An Example of kadin creek (Mugla, Turkey). Braz Arch Biol Technol, 57, 434-440. 